\title{
Screening Growth Promoting Traits in Maize Using Native Rhizobacteria through Multiple Approaches
}

\author{
Shilpa G.S. and Jibu Thomas* \\ Department of Biotechnology, School of Agriculture and Biosciences, Karunya Institute of Technology and Sciences \\ (Deemed to be University), Coimbatore - 641 114, India.
}

\begin{abstract}
Plant growth promoting rhizobacteria (PGPR) are the soil bacteria that enhance the growth and yield of any plant via synthesis of plant growth promoting substances. The use of beneficial soil microorganisms such as PGPR for sustainable and safe agriculture has increased in last decade, because of the negative impact of artificial fertilizer. The present study involves developing two formulations viz., Talc and liquid and to evaluate the efficacy of potential plant growth promoting rhizobacteria as foliar formulation on the growth and development of maize plant. Five different isolates viz., $F_{3} 20, F_{3} 53, F_{4} 12, F_{2} 12, F_{1} 19$ were used in the present study and maize seeds were treated with PGPR isolates for evaluation of germination using paper towel method, green house condition and their growth parameters were measured. Solid formulation and foliar spray were prepared out of these $\mathbf{5}$ isolates for field trials. Talc was used as carrier material for preparing solid formulation by mixing isolates with sterilized carrier material and used in field trials. The broth of the isolates was filtered and the filtrate was used as liquid formulation. Observation on germination percentage, growth and development of maize plant was recorded. The study concluded that liquid and talc formulation has shown better results when compared to that of control. Among these five isolates $F_{3} 20$ has shown better results and foliar spray has shown greater impact in plant growth when compared to that of talc formulation in field study.

Keywords: Plant Growth Promoting Rhizobacteria, Paper towel method, Pot experiment, Formulation, Foliar spray, Field trails.
\end{abstract}

\footnotetext{
*Correspondence: jibuthomas.t@gmail.com

(Received: 28 November 2018; accepted: 19 January 2019)

Citation: Shilpa G.S. and Jibu Thomas, Screening Growth Promoting Traits In Maize Using Native Rhizobacteria Through Multiple Approaches, J Pure Appl Microbiol., 2019; 13(1):355-360 doi: 10.22207/JPAM.13.1.39

(C) The Author(s) 2019. Open Access. This article is distributed under the terms of the Creative Commons Attribution 4.0 International License which permits unrestricted use, sharing, distribution, and reproduction in any medium, provided you give appropriate credit to the original author(s) and the source, provide a link to the Creative Commons license, and indicate if changes were made.
} 


\section{INTRODUCTION}

The major chronic threat to sustainable agriculture is pathogenic microorganisms that affect the plant growth and yield. Though the usage of chemical fertilizer has contributed great increase in food production by controlling the pathogenic microorganism, pests and disease, the usage of chemical fertilizer in long term basis has led to reduction in $\mathrm{pH}$ of the soil which reduces the productivity of the soil and numerous ecological problems like draining away of nutrient from the soil which affects the practice of sustainable agriculture ${ }^{5}$.

To overcome the problems related to pathogenic bacteria and chemical fertilizer, the alternative method followed is the usage of plant growth promoting rhizobacteria (PGPR). The rhizobacteria have increase water uptake capacity and tolerance against heavy metals ${ }^{7}$. They consist of various beneficial bacteria which enhances the growth of the plant. There are large number of microbial populations under the influence of root system which are capable of exerting beneficial effects on plant growth in the rhizosphere region ${ }^{9}$.

Plant Growth Promoting Rhizobacteria (PGPR) actively colonize plant roots and enhances plant growth and yield ${ }^{8}$. In soil ecosystem there are different bacterial genere that involve in various biotic activities like nutrient uptake and helps in practicing sustainable agriculture ${ }^{1}$. The PGPR enhances the plant growth through mobilizing nutrients in soils, and enhances the production of numerous plant growth regulators, controlling or inhibiting the plant pathogens that affects the plant growth, improves soil structure and sequester toxic heavy metals and pesticides present in the soil'. The present study is aimed at developing two different formulations of five different isolates of potential plant growth promoting rhizobacteria viz., $F_{3} 20, F_{3} 53, F_{4} 12, F_{2} 12$, $F_{1} 19$ as Talc and liquid and to evaluate their efficacy on the growth and development of maize plant.

\section{MATERIALS AND METHODS}

The PGPR used for the present study were coded as $F_{3} 20, F_{3} 53, F_{4} 12, F_{2} 12, F_{1} 19$. Talc is used as carrier material for solid formulation. The sweet corn seeds used were a composite of 85 to 90 days cycle variety called Sugar 75 .

\section{Isolation of PGPRs}

Strains of PGPR were isolated from native agricultural soil by serial dilution and plating method. Pure culture was maintained and was stored in refrigerator after labelling as glycerol stock culture at $-20^{\circ} \mathrm{C}$. These subcultures were inoculated in bacterial broth culture and used for the experiment.

\section{Effect on germination and seedling growth using} PGPR

The experiments were conducted in laboratory, green house condition and field trial respectively. In the experiment conducted in laboratory and in green house condition, the maize seeds were surface sterilized and mixed with PGPR isolates and tested in paper towel method and pot experiment. ${ }^{4}$

\section{Paper Towel Method}

Seeds treated with PGPR and control were placed in the first germination sheet in a row. Moisten the second germination sheet and place it over the first germination sheet and carefully roll them leaving the seeds sandwiched in between two sheets and place in bottle filled with water that will retain the moisture and place the bottle away from sunlight. The morphometric analyses of the germinated seeds were done on the $15^{\text {th }}$ day to select the best isolates that influences germination.

\section{Pot experiment}

The sterilized soil was weighed, filled in each plastic pots and the seeds treated with PGPR and control were placed in soil. The entire incubation was done in green house condition where $\mathrm{pH}$ and temperature were regulated. The treatment consisted of 30 plants i.e., three replicates with 10 seeds per plot. Seedlings were watered daily and after 15 days morphometric analysis of the germinated seeds were done.

\section{Field Trials}

The experiment conducted in field trial involves two different formulation viz., Liquid formulation for foliar spray and Solid formulation for root application. Talc is used as carrier material to prepare the solid formulation. The bacterial broth culture is mixed well with the sterilized carrier material and used as formulation in field trials. For liquid formulation, the broth of the isolates was filtered using membrane filter and 
Table 1. Treatment involved in field trails.

\begin{tabular}{ll}
\hline S.No. & \multicolumn{1}{c}{ Treatments } \\
\hline 1. & Control \\
2. & Talc formulation $\mathrm{F}_{3} 20$ \\
3. & Talc formulation $\mathrm{F}_{3} 53$ \\
4. & Talc formulation $\mathrm{F}_{4} 12$ \\
5. & Talc formulation $\mathrm{F}_{2} 12$ \\
6. & Talc formulation $\mathrm{F}_{1} 19$ \\
7. & Foliar application $\mathrm{F}_{3} 20$ \\
8. & Foliar application $\mathrm{F}_{3} 53$ \\
9. & Foliar application $\mathrm{F}_{4} 12$ \\
10. & Foliar application $\mathrm{F}_{2} 12$ \\
11. & Foliar application $\mathrm{F}_{1} 19$ \\
12. & Talc and Foliar application $\mathrm{F}_{3} 20$ \\
13. & Talc and Foliar application $\mathrm{F}_{3} 53$ \\
14. & Talc and Foliar application $\mathrm{F}_{4} 12$ \\
15. & Talc and Foliar application $\mathrm{F}_{2} 12$ \\
16. & Talc and Foliar application $\mathrm{F}_{1} 19$ \\
\hline
\end{tabular}

the filtrate used as foliar spray in field trials. To study the effect of PGPR formulation in growth and development of sweet corn an experiment was carried in the field. There were 4 treatments which include the control, solid formulation, liquid formulation and combination of liquid and solid formulation (Table 1). Randomized block design model is used to arrange the treatments. The seeds were placed above the solid formulation in a furrow. Each treatment was replicated three times. The field was watered daily and no chemical fertilizer were applied ${ }^{4}$.

\section{RESULTS AND DISCUSSION \\ Observation in effects of PGPR on various growth parameters of maize \\ Paper towel method}

The PGPR used for the present study labelled as $F_{3} 20, F_{3} 53, F_{4} 12, F_{2} 12, F_{1} 19$ were compared with control to study the various growth parameters of sweet corn such as shoot length, root length, no. of. leaves, fresh and dry weight of root and shoot. Results showed that shoot length varied between $13.50 \mathrm{~cm}$ to maximum of $18.81 \mathrm{~cm}$. Among these five isolates $F_{3} 20$, showed more length than control in terms of plant height which was 13.50 and $15.28 \mathrm{~cm}$ respectively. Similar results were obtained for root length and for other growth parameters. The observation of paper towel method were shown in Fig. 1. Results of all parameters indicated that PGPR formulations of $F_{3} 20, F_{3} 53, F_{4} 12, F_{2} 12, F_{1} 19$ was found to influence various growth parameters. Among the isolate tested $\mathrm{F}_{3} 20$ had a significant improvement in value of all the parameters studied. The results are tabulated in Table 2.

\section{Pot Experiment}

Result shows that shoot length varied between $15.27 \mathrm{~cm}$ to maximum of $25.5 \mathrm{~cm}$. Among these five isolates $F_{3} 20$ showed more length $(25.5 \mathrm{~cm})$ which is more than control height which was $15.27 \mathrm{~cm}$. Similar results were obtained for root length and for other growth parameters also. The results of all parameters indicated that

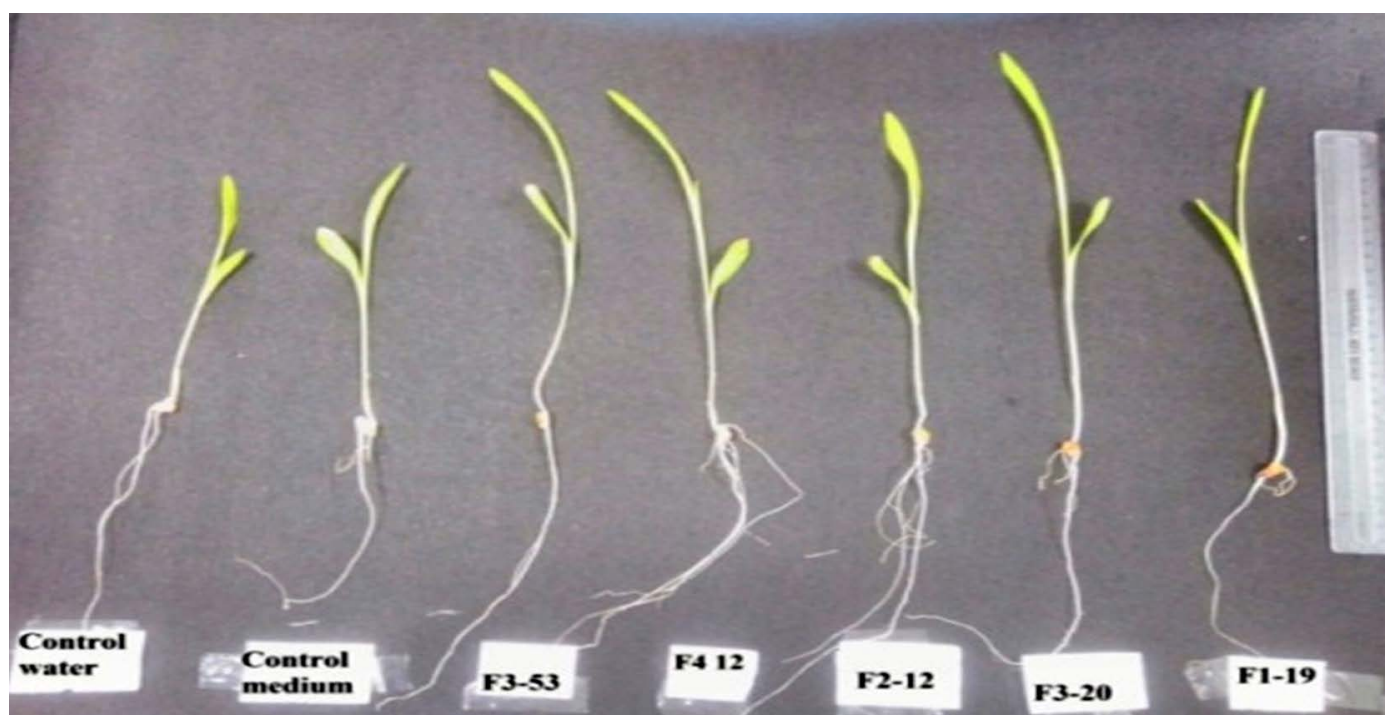

Fig. 1. Observation of paper towel method 
Table 2. Morphometric data of seedlings in paper towel method.

\begin{tabular}{lccccccc}
\hline $\begin{array}{l}\text { Growth } \\
\text { Parameter }\end{array}$ & $\begin{array}{c}\text { Control } \\
\text { (medium) }\end{array}$ & $\begin{array}{c}\text { Control } \\
\text { (water) }\end{array}$ & $\mathrm{F}_{3} 20$ & $\mathrm{~F}_{3} 53$ & $\mathrm{~F}_{4} 12$ & $\mathrm{~F}_{2} 12$ & $\mathrm{~F}_{1} 19$ \\
\hline No. of. leaves & 1.33 & 1.23 & 1.8 & 1.4 & 1.67 & 1.6 & 1.6 \\
No. of. roots & 3.8 & 3.4 & 7.2 & 3.8 & 4.06 & 5.33 & 3.9 \\
Shoot length (cm) & 15.28 & 13.50 & 18.81 & 13.01 & 17.56 & 17.90 & 17.58 \\
Root length(cm) & 16.92 & 13.69 & 20.97 & 15.96 & 18.67 & 17.94 & 18.01 \\
Shoot fresh weight (g) & 0.308 & 0.284 & 0.333 & 0.239 & 0.335 & 0.334 & 0.322 \\
Root fresh weight(g) & 0.221 & 0.188 & 0.288 & 0.181 & 0.239 & 0.263 & 0.227 \\
Shoot dry weight (g) & 0.056 & 0.053 & 0.078 & 0.074 & 0.089 & 0.110 & 0.077 \\
Root dry weight(g) & 0.046 & 0.033 & 0.043 & 0.038 & 0.046 & 0.059 & 0.039 \\
\hline
\end{tabular}

PGPR formulations of $F_{3} 20, F_{3} 53, F_{4} 12, F_{2} 12, F_{1} 19$ was found to give positive influence on various growth parameters. Among the isolate tested $\mathrm{F}_{3} 20$ had a significant improvement in value of all the parameters which is followed by $F_{1} 19$ and $F_{2} 12$ isolates. The results are tabulated in Table 3.

\section{Field trial}

The field trail involved carrier based formulations i.e, Talc formulation, foliar spray and combination of both. Shoot length in talc formulation treatment was between 16.23 to
39.66, in plant which treated with both talc and foliar spray was between 30.8 to 51.4 and plant which is treated with foliar spray alone ranged from 44.48 to $56.9 \mathrm{~cm}$. Similar results were obtained in root length, no.of.leaves, no. of. roots, shoot and root fresh and dry weight. It was observed from the Table 4 that almost all parameters have responded well. Comparatively foliar spray was found superior among other treatments. Fig. 2 . shows the morphometric observation of uprooted plants in field trials.
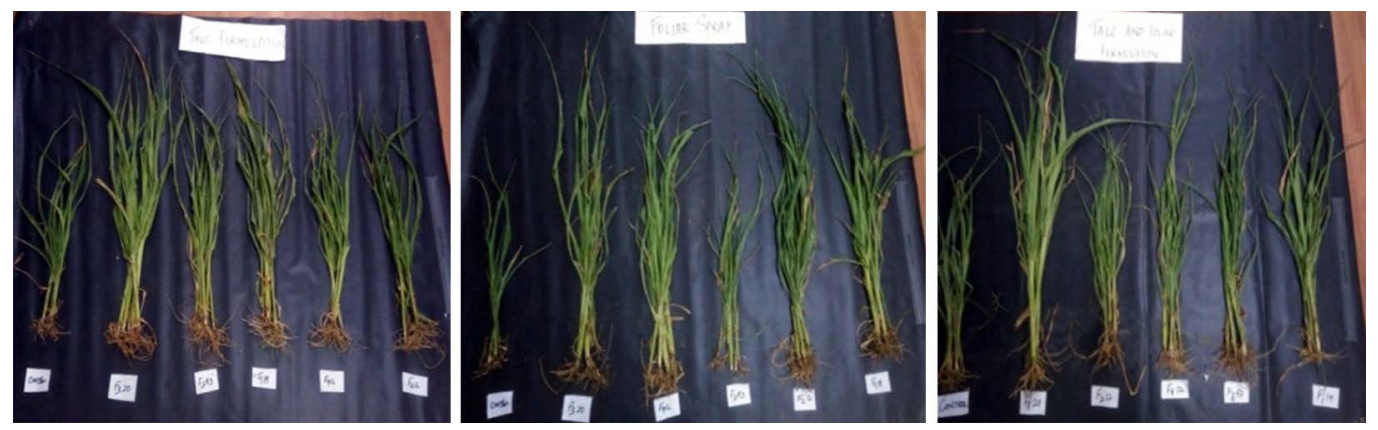

Fig. 2. Morphometric observation of uprooted plants in field trials

Table 3. Morphometric data of seedlings in pot experiment.

\begin{tabular}{lccccccc}
\hline $\begin{array}{l}\text { Growth } \\
\text { parameters }\end{array}$ & $\begin{array}{l}\text { Control } \\
\text { (water) }\end{array}$ & $\begin{array}{c}\text { Control } \\
\text { (medium) }\end{array}$ & $\mathrm{F}_{3} 20$ & $\mathrm{~F}_{3} 53$ & $\mathrm{~F}_{1} 19$ & $\mathrm{~F}_{2} 12$ & $\mathrm{~F}_{4} 12$ \\
\hline No.of.leaves & 1.86 & 1.98 & 3.13 & 2.06 & 2.63 & 2.60 & 2.04 \\
No.of.roots & 1.17 & 3.20 & 4.73 & 3.23 & 4.2 & 3.4 & 2.93 \\
Shoot length (cm) & 15.27 & 15.91 & 25.5 & 17.04 & 21.10 & 21.01 & 16.78 \\
Root length(cm) & 2.66 & 3.20 & 4.94 & 3.44 & 4.90 & 4.53 & 3.38 \\
Shoot fresh weight (g) & 0.503 & 0.507 & 0.717 & 0.470 & 0.618 & 0.559 & 0.415 \\
Root fresh weight(g) & 0.201 & 0.220 & 0.323 & 0.211 & 0.228 & 0.225 & 0.200 \\
Shoot dry weight (g) & 0.056 & 0.070 & 0.088 & 0.059 & 0.085 & 0.070 & 0.054 \\
Root dry weight(g) & 0.026 & 0.035 & 0.066 & 0.041 & 0.056 & 0.052 & 0.047 \\
\hline Journal of Pure and Applied Microbiology & & & & & & & \\
\hline
\end{tabular}


Table 4. Morphometric data of seeds germinated in field trials

\begin{tabular}{|c|c|c|c|c|c|c|c|c|c|c|c|c|c|c|c|c|}
\hline \multirow{2}{*}{$\begin{array}{l}\text { Growth } \\
\text { Para- } \\
\text { meters }\end{array}$} & \multirow[t]{2}{*}{ Control } & \multicolumn{5}{|c|}{ Talc formulation } & \multicolumn{5}{|c|}{ Foliar Spray } & \multicolumn{5}{|c|}{ Talc and Foliar spray } \\
\hline & & $\mathrm{F}_{3} 20$ & $\mathrm{~F}_{3} 53$ & $\mathrm{~F}_{4} 12$ & $\mathrm{~F}_{2} 12$ & $\mathrm{~F}_{1} 19$ & $\mathrm{~F}_{3} 20$ & $\mathrm{~F}_{3} 53$ & $\mathrm{~F}_{4} 12$ & $\mathrm{~F}_{2} 12$ & $F_{1} 19$ & $\mathrm{~F}_{3} 20$ & $\mathrm{~F}_{3} 53$ & $\mathrm{~F}_{4} 12$ & $\mathrm{~F}_{2} 12$ & $F_{1} 19$ \\
\hline $\begin{array}{l}\text { No. of } \\
\text { leaves }\end{array}$ & 2.13 & 5.93 & 3.5 & 2.90 & 2.3 & 2.86 & 6.5 & 4.6 & 5.1 & 4.16 & 5.7 & 6 & 4.3 & 4.7 & 3.83 & 3.9 \\
\hline $\begin{array}{l}\text { No.of } \\
\text { roots }\end{array}$ & 3.26 & 9.66 & 6.85 & 5.72 & 5 & 5.63 & 11.43 & 9.12 & 10.23 & 9.36 & 10.76 & 9.86 & 9.06 & 8.6 & 7.8 & 6.33 \\
\hline $\begin{array}{l}\text { Root } \\
\text { length } \\
(\mathrm{cm})\end{array}$ & 3.2 & 10.66 & 3.5 & 7.5 & 4.93 & 6.1 & 15.55 & 15.53 & 10.96 & 12.2 & 11.73 & 15.2 & 15.2 & 10.36 & 11.93 & 7.6 \\
\hline $\begin{array}{l}\text { Shoot } \\
\text { length } \\
(\mathrm{cm})\end{array}$ & 13.03 & 39.66 & 6.87 & 20.53 & 16.23 & 19.7 & 56.9 & 51.4 & 37.03 & 39.6 & 44.48 & 51.4 & 39.66 & 36.73 & 30.8 & 31.8 \\
\hline $\begin{array}{l}\text { Root } \\
\text { fresh } \\
\text { weight(g) }\end{array}$ & 0.14 & 0.75 & 0.33 & 0.52 & 0.20 & 0.29 & 0.98 & 0.40 & 0.78 & 0.55 & 0.66 & 0.100 & 0.35 & 0.55 & 0.44 & 0.37 \\
\hline $\begin{array}{l}\text { Shoot } \\
\text { fresh } \\
\text { weight(g) }\end{array}$ & 1.38 & 12.67 & 3.23 & 6.25 & 1.65 & 2.89 & 13.86 & 6.37 & 8.01 & 12.84 & 11.68 & 13.86 & 6.14 & 6.97 & 5.6 & 6.5 \\
\hline $\begin{array}{l}\text { Root } \\
\text { dry } \\
\text { weight(g) }\end{array}$ & 0.07 & 0.32 & 0.17 & 0.17 & 0.11 & 0.13 & 0.41 & 0.48 & 0.25 & 0.22 & 0.28 & 0.35 & 0.20 & 0.20 & 0.19 & 0.20 \\
\hline $\begin{array}{l}\text { Shoot dry } \\
\text { weight(g) }\end{array}$ & 0.69 & 5.14 & 1.87 & 2.80 & 1.99 & 2.48 & 7.89 & 3.06 & 5.03 & 5.18 & 7.59 & 6.44 & 2.78 & 4.12 & 1.65 & 5.54 \\
\hline
\end{tabular}

Among the isolates, $F_{3} 20$ was found performing well in the field when compared to other isolates. The performance of $\mathrm{F}_{3} 20$ as foliar spray showed significant growth, which is evident from all parameters concerned, when compared to control.

The study clearly proved that PGPR have the potential to enhance the plant growth through various mechanism and may help to reduce chemical fertilizer inputs. Continuous usage of chemical fertilizer in agricultural soil, makes soil unfertile and hence usage of PGPR strains enhances soil fertility and increase the growth and yield of crop. Study proved that the inoculation of PGPR strains enhanced all the parameters in field trails and positive results in growth and yield of maize may be due to $\mathrm{N}_{2}$ fixation, phosphate solubilisation and phyto-hormone production ${ }^{3}$. In countries, where agricultural inputs remains relatively expensive, application of PGPR as formulations can be promoted for the development of organic agriculture. PGPR strains colonize roots at average population density and increases the growth when compared to control, which was observed in field trails. ${ }^{6}$ Similar improvements have been seen in other cereals when inoculated with rhizobacteria.

\section{CONCLUSION}

Study conducted that using the five different PGPR isolates $\left(F_{3} 20, F_{3} 53, F_{4} 12, F_{2} 12\right.$, $\left.F_{1} 19\right)$ evaluated for the growth of maize plant revealed that there is significant improvement in the growth parameters like root and shoot length, no. of. leaves, no. of. roots, shoot and root fresh and dry weight. Among the five isolates, isolate $\mathrm{F}_{3} 20$ was found to be performing well in the paper towel method and pot trials. The study conducted on field trial concludes that $\mathrm{F}_{3} 20$ as foliar spray showed significant growth which is evident from all parameters concerned when compared to control. Hence, the usage of isolate $\mathrm{F}_{3} 20$ as PGPR was found to be suitable. There is enormous scope for upscaling this technology for the benefit of the farming community and to improve sustainable and eco-friendly agriculture. 


\section{ACKNOWLEDGMENTS}

Authors are thankful to Algae Biomass Research Lab and Karunya Institute of Technology and Sciences (Deemed to be University) for all the support extended during the study. Task force project of DBT, Govt. of India (BT/PR4683/ AGR/21/353/2012) is thankfully acknowledged.

\section{AUTHORS CONTRIBUTION}

Shilpa GS conducted the experiment, collected the data and drafted the article. Dr. Jibu Thomas designed the experiment, supervised the data collected and reviewed the article.

\section{CONFLICTS OF INTEREST}

The author declares that there are no conflict of interest.

\section{REFERENCES}

1. Ahemad M, Khan M.S. Effect of insecticide tolerant and plant growth promoting mezorhizobium on the performance of chickpea on grown in insecticide stressed alluvial soils. Journal of Crop Science and Biotechnology, 2009; 12: 213-222.

2. Ahemad M, Mailk A. Bioaccumulation of heavy metals by zinc resistant bacteria isolated from agricultural soils irrigated with waste water. Bacteriology Journal, 2011; 2: 12-20.

3. Egamberdiyeva D. The effect of plant growth promoting bacteria on growth and nutrient uptake of maize in two different soils. Appl. Soil Ecol., 2007; 36: 184-189.

4. Gholami S, Shahsavani, Nezarat S. The Effect of Plant Growth Promoting Rhizobacteria (PGPR) on Germination, Seedling Growth and Yield of Maize, International Journal of Biological, Biomolecular, Agricultural, Food and Biotechnological Engineering, 2009; 3: 9-14.

5. Govind Gupta, Parihar, Ahirwar, Snehi Singh V. Plant Growth Promoting Rhizobacteria (PGPR): Current and Future Prospects of Development of Sustainable Agriculture Journal of Microbiology Biochemistry Technology, 2015; 7: 096-102.

6. Joseph W Kloepper, Robert M Zalblotowicz, Elizabeth $M$ Tipping, Ran Lifhitz. Plant growth promotion mediated by bacterial rhizosphere colonizers, 1991, pp. 315-326. D.L.Keister and P.B.Cregan (eds.), The rhizosphere and plant growth.

7. Maxton, Ann, Singh P, Aruna A, Prasad S.M, Masih S.A. PGPR: A boon in stress tolerance and bio control. Res. J. Biotechnol., 2018; 13: 105-111.

8. Pacome Noumavo A, Emeric Kochoni, Yedou Didagbe, Adolphe Adjanohoun, Marcellin Allagbe, Rachidatou Sikirou, Emma Gachamo, Simeon Kotchoni, Lamine Baba Maussa. Effect of Different Plant Growth Promoting Rhizobacteria on Maize seed Germination and Seedling Development, Am. J. Plant Sci., 2013; 4: 1013-1021.

9. Pavan Agarwal, Shruti Agarwal. Characterization of Bacillus sp. strains isolated from rhizosphere of tomato plants (Lycoperiscon esculentum) for their use as potential plant growth promoting rhizobacteria. Int. J. Curr. Microbiol. App. Sci., 2013; 2: 406-417. 